\title{
Reply to the Letter "The Stability of Blood Gas Parameters Depends on Leukocyte Count"
}

\author{
Ariadna Arbiol-Roca (), Ph.D. and Claudia Elizabeth Imperiali (), Ph.D. \\ Laboratori Clínic Territorial Metropolitana Sud-Hospital Universitari de Bellvitge, Hospitalet de Llobregat, Barcelona, Spain
}

\section{Dear Editor,}

We would like to thank Vaudran, et al. [1] for their letter in response to our article "Stability of $\mathrm{pH}$, blood gas partial pressure, hemoglobin oxygen saturation fraction, and lactate concentration" [2]. We agree with the issues raised by the authors.

In our study, we had acquired complete blood count data of each sample and had preliminarily analyzed whether leukocyte count affected the stability of $\mathrm{pH}$, partial pressure of carbon dioxide $\left(\mathrm{pCO}_{2}\right)$ and oxygen $\left(\mathrm{pO}_{2}\right)$, hemoglobin oxygen saturation $\left(\mathrm{sO}_{2}\right)$, and lactate concentration through a logistic regression model [2].

We observed that leukocytosis impairs the stability of $\mathrm{pH}$ and $\mathrm{pCO}_{2}$ in blood samples at room temperature $\left(25^{\circ} \mathrm{C}\right)$. The logistic regression model revealed an association of decreased $\mathrm{pH}(P=$ $0.041)$ and increased $p \mathrm{CO}_{2}(P=0.034)$ with increased leukocyte count because leukocyte metabolism promotes acidosis (Table 1). However, in samples stored under our recommended condition ( 45 minutes at $0-3.9^{\circ} \mathrm{C}$ ), we found no association of $\mathrm{pH}$ and $\mathrm{pCO}_{2}$ with leukocyte count $(P>0.05)$. Therefore, it is likely that storage at low temperatures $\left(0-3.9^{\circ} \mathrm{C}\right)$ reduces leukocyte metabolism in samples and thus, leukocyte count would not affect the stability of blood gas parameters.

The flow chart proposed by the Vaudran, et al. [1] seems very consistent and useful in daily clinical practice. Nevertheless, when leukocyte count cannot be determined, we still recommend storing samples at $0-3.9^{\circ} \mathrm{C}$ for a maximum of $45 \mathrm{~min}$ utes.

\section{ACKNOWLEDGEMENTS}

We thank all laboratory staff who were involved in the study.

\section{AUTHOR CONTRIBUTIONS}

Arbiol-Roca A and Imperiali CE were involved in the study conception, design, data acquisition, analysis, and interpretation as well as drafting, reviewing, and editing of the manuscript. Both the authors read and approved the final manuscript.

\section{CONFLICTS OF INTEREST}

The authors declare no conflicts of interest.

\section{RESEARCH FUNDING}

This study was supported by a grant from Fundación JL CastañoSEQC "María Rosa Concustell 2013".
Received: January 29, 2021

Revision received: February 16, 2021

Accepted: March 23, 2021

Corresponding author: Ariadna Arbiol-Roca, Ph.D.

Laboratori Clínic Territorial Metropolitana Sud-Hospital Universitari de Bellvitge, 08907 Hospitalet de Llobregat, Barcelona, Spain Tel: +34932607500, E-mail: ariadna.arbiol@bellvitgehospital.cat

\section{(c) (1) $(9$}

\section{(C) Korean Society for Laboratory Medicine}

This is an Open Access article distributed under the terms of the Creative Commons Attribution Non-Commercial License (https://creativecommons.org/licenses/by-nc/4.0) which permits unrestricted non-commercial use, distribution, and reproduction in any medium, provided the original work is properly cited. 
Arbiol-Roca A, et al.

Reply to the letter by Vaudran L, et al., 2021

Table 1. Logistic regression model of the effect of leukocyte count $\left(\times 10^{9} / \mathrm{L}\right)$ on the stability of $\mathrm{pH}, \mathrm{pCO}_{2}, \mathrm{pO}_{2}, \mathrm{sO}_{2}$, and lactate concentration at room temperature $\left(25^{\circ} \mathrm{C}\right)$

\begin{tabular}{lccc}
\hline & $P$ & OR & $95 \% \mathrm{Cl}$ \\
\hline $\mathrm{pH}$ & 0.041 & 0.981 & $0.963-0.999$ \\
$\mathrm{pCO}_{2}(\mathrm{~mm} \mathrm{Hg})$ & 0.034 & 1.019 & $1.001-1.037$ \\
$\mathrm{pO}_{2}(\mathrm{~mm} \mathrm{Hg})$ & 0.157 & - & - \\
$\mathrm{sO}_{2}(\%)$ & 0.314 & - & - \\
Lactate $(\mathrm{mmol} / \mathrm{L})$ & 0.173 & - & -
\end{tabular}

Abbreviations: $\mathrm{Cl}$, confidence interval; $\mathrm{OR}$, odds ratio; $\mathrm{pCO}_{2}$, partial pressure of carbon dioxide; $\mathrm{pO}_{2}$, partial pressure of oxygen; $\mathrm{sO}_{2}$, hemoglobin oxygen saturation.

\section{ORCID}

Ariadna Arbiol-Roca $\quad$ https://orcid.org/0000-0002-5206-3818 Claudia Elizabeth Imperiali https://orcid.org/0000-0002-7130-922X

\section{REFERENCES}

1. Vaudran L, Pekar JD, Grzych G, Maboudou P. The stability of blood gas parameters depends on leukocyte Count. Ann Lab Med 2021;41:5: 530-1.

2. Arbiol-Roca A, Imperiali CE, Dot-Bach D, Valero-Politi J, Dastis-Arias M. Stability of $\mathrm{pH}$, blood gas partial pressure, hemoglobin oxygen saturation fraction, and lactate concentration. Ann Lab Med 2020;40:448-56. 